\title{
Coalition Agreements, Issue Attention, and Cabinet Governance
}

Comparative Political Studies 2019, Vol. 52(13-14) 1995-2031

(C) The Author(s) 2019

Article reuse guidelines: sagepub.com/journals-permissions DOI: $10.1177 / 0010414019830726$ journals.sagepub.com/home/cps

@SAGE

\section{Heike Klüver' ${ }^{(D)}$ and Hanna Bäck²}

\begin{abstract}
Why do coalition parties settle some policy issues in great detail, whereas other issues are hardly mentioned in coalition agreements? Coalition agreements are important policy platforms that determine policy making during the legislative term. However, we know remarkably little about their content. We shed light on why issue attention in coalition agreements varies so extensively. We argue that intra-cabinet conflict positively affects issue attention as parties have stronger incentives to negotiate a detailed policy agenda that constrains their coalition partners. However, we expect that this effect is conditioned by preference tangentiality and the salience of an issue among coalition partners. Our theoretical expectations are tested drawing on a new data set based on a comprehensive content analysis of 224 agreements negotiated by 181 parties between 1945 and 2015 in 24 West and East European countries. We find support for our hypotheses and conclude that parties draft agreements to limit "ministerial drift."
\end{abstract}

\section{Keywords}

coalition governments, coalition agreements, cabinets, european politics, political parties

\section{Introduction}

Coalition agreements are important policy platforms that crucially determine policy making and coalition governance during the legislative term. Before

\footnotetext{
'Humboldt-Universität zu Berlin, Germany

${ }^{2}$ Lund University, Sweden
}

\section{Corresponding Author:}

Heike Klüver, Humboldt-Universität zu Berlin, Unter den Linden 6, 10099 Berlin, Germany.

Email: heike.kluever@hu-berlin.de 
taking over executive offices, coalition parties engage in lengthy coalition negotiations, bargaining over their joint policy agenda that is written down in public coalition agreements (Müller \& Strøm, 2008). Although these "contracts" are not legally binding, previous research has shown that they significantly constrain the behavior of coalition partners (see, for example, Bäck, Müller, \& Nyblade, 2017). Schermann and Ennser-Jedenastik (2014), for instance, show that election pledges to which coalition governments commit themselves in their coalition agreements are significantly more likely to be fulfilled throughout the legislative term. Similarly, Timmermans and Breeman (2011) find that there is correspondence between issue priorities defined in the coalition agreement and the legislative agenda of coalition governments in the Netherlands.

However, despite the central importance of coalition agreements for coalition governance and policy making, we know remarkably little about what determines their content. The small number of empirical studies of coalition agreements that do exist have focused on explaining either the presence of coalition agreements or their overall length, or the variation in how comprehensively policies or procedural rules are generally covered (e.g., Bowler, Bräuninger, Debus, \& Indridason, 2016; Eichorst, 2014; Indridason \& Kristinsson, 2013; Moury \& Timmermans, 2013; Strøm \& Müller, 1999; Strøm, Müller, \& Bergman, 2008). We instead focus on explaining the variation in issue attention across coalition agreements, centering on the fact that coalition partners settle some policy issues in great detail, whereas other issues are hardly mentioned in the agreement. We, thus, fill an important gap in the literature by shedding light on why the attention that coalition parties devote to different policy issues in coalition agreements varies so extensively.

We know from previous literature on issue competition that political parties importantly differentiate between different policies (e.g., Budge \& Farlie, 1983; Green-Pedersen 2007; Klüver \& Spoon, 2016; Petrocik, 1996; van de Wardt, de Vries, \& Hobolt, 2014). For instance, imagine a coalition government in which there is severe conflict between coalition partners on economic policy, whereas they largely agree on civil rights. We argue that such a cabinet would devote a lot of attention to economic policy in its coalition agreement, prescribing a detailed policy agenda to leave little room of maneuver for their partners to prevent shirking in this contested domain. However, we expect that civil rights issues should hardly be mentioned in the agreement, as there is no need to engage in lengthy bargaining because the partners have similar views on the issue. At the aggregate level, the differences between these issues would cancel each other out, so that merely looking at the overall length of coalition agreements overlooks important 
variation within cabinets. We accordingly posit that just focusing on the length of coalition agreements is not sufficient to understand how divisiveness within the cabinet affects coalition agreements. Instead, we suggest that a dependent variable focusing on how much coverage specific issues receive in the coalition agreement, what we here call "issue attention," is much more appropriate.

We develop a theoretical argument where we focus on explaining "issue attention" in coalition agreements, drawing on the previous literature on coalition governance, which suggests that parties entering multiparty cabinets in parliamentary democracies are likely to implement various control mechanisms to limit "agency loss" when power is delegated to individual ministers (see, for example, Müller \& Meyer, 2010; Strøm, Müller, \& Smith, 2010). We argue that ideological conflict in coalition cabinets positively affects issue attention as coalition parties have stronger incentives to negotiate a detailed policy agenda that constrains their coalition partners when intra-cabinet conflict is high (Indridason \& Kristinsson, 2013). However, we expect that this effect is conditioned by preference tangentiality and the overall salience of policy issues among cabinet partners as the incentives to engage in lengthy negotiations about a policy compromise increases with the salience of an issue, but decreases as tangentiality rises.

Our main contribution is empirical: First, we are able to more properly evaluate an argument about the impact of intra-coalition conflict on the drafting of coalition agreements by focusing on how issue attention varies across agreements. We suggest that an analysis where overall agreement length is used as a dependent variable is inappropriate because it is likely to overlook important variation within agreements as some issues may receive high attention, whereas others are hardly mentioned in the same agreement. Ignoring the variation within agreements may in fact lead to an underestimation of the effect of intra-coalition conflict on the drafting of coalition agreements because the impact of conflict on some issues may be canceled out by a lack of conflict on some other issues. Second, we clearly contribute empirically to the previous literature by providing a novel and comprehensive data set that, for the first time, maps the policy content of coalition agreements across issues. This data set is also the largest data set on coalition agreements that exists, as most studies have analyzed agreements in Western Europe only. We are, thus, able to evaluate hypotheses about intra-coalition conflict and the content of coalition agreements, drawing on a new comparative data set on coalition agreements generated by a comprehensive quantitative content analysis of agreements in 24 West and East European countries from 1945 until 2015. Using this novel data set, we test our hypotheses studying 224 coalition agreements negotiated by 181 political parties. 
The results show support for our hypotheses: Ideological conflict importantly matters for how much attention is given to specific policy issues in the coalition agreement, but its effect is conditioned by preference tangentiality and the joint salience of an issue among coalition partners. Parties are clearly more likely to spend a lot of effort on negotiating and agreeing on issues that are divisive within the coalition, especially if they have overlapping preferences, that is, when similar issues are salient to several partners. Our results suggest that parties draft agreements to limit "ministerial drift" and have important implications for our understanding of coalition governance in parliamentary democracies.

\section{Previous Research on Coalition Agreements}

Strøm and Müller (1999) set the agenda for the empirical study of coalition contracts, introducing a comparative data set on coalition agreements in 13 Western European countries (1945-1996), showing that three different points are typically settled in coalition treaties: policy agreements, portfolio allocation, and procedural rules. This data set, which was later extended (Strøm et al., 2008), records whether a coalition had drafted a formal or informal agreement, provides data on the length of agreements measured by the number of words they contain, and includes a measure for how comprehensively policies were negotiated, measured by the share of the content devoted to policies more generally.

Several studies have focused on the impact of coalition agreements. For example, Moury and Timmermans (2013) study coalition agreements in Germany, Belgium, Italy, and the Netherlands, focusing on whether the agreements include deals on policy issues that the governing parties do not agree on. Moury (2011) analyzes how coalition agreements constrain the impact of ministers on policy decisions. Bäck et al. (2017) focus on the role of coalition agreements in solving so-called "common pool problems." Analyzing spending behavior in 17 Western European countries, they find that coalition agreements significantly reduce the negative effect of government fragmentation on spending in institutional contexts where prime ministerial power is low. Schermann and Ennser-Jedenastik (2014) show that election pledges to which governments commit themselves in their coalition agreements in Austria are more likely to be fulfilled throughout the legislative term. Similarly, Timmermans and Breeman (2011) find that there is correspondence between issue priorities defined in the coalition agreement and the legislative agenda of coalition governments in the Netherlands. Timmermans (2006) focuses on the role of agreements in managing conflicts, and suggests that written coalition agreements are drafted to "reduce mistrust 
and uncertainty" among party leaders (p. 265). He also argues that parties should focus on points that divide them, and that the agreement enables the party leaders to publicly "establish a policy equilibrium."

Some recent scholarly work focuses on explaining the existence and the overall length of coalition agreements, drawing primarily on the data set provided by Strøm et al. (2008). For example, Indridason and Kristinsson (2013) argue that coalition agreements are a mechanism for avoiding "ministerial drift." They suggest that in cases where the moral hazard problem is serious, we should expect coalition agreements to be negotiated and to be more extensive. Empirically, they focus on 227 cabinets in 13 Western European countries, and the dependent variables in their analysis describe whether an agreement was negotiated at all, and how long the agreement was. Indridason and Kristinsson (2013) conclude that the length of coalition agreements increases with factors "likely to exacerbate the moral hazard problem," for example, as the ideological diversity between partners increases (p. 840). Using a somewhat different dependent variable, Eichorst (2014) focuses on the number of words dedicated to policy language in the agreements (see Huber \& Shipan, 2002). Analyzing agreements in 12 Western European countries, he finds that parties include high-salience issues in the agreement on policy dimensions where they are more divided.

Falcó-Gimeno (2014) presents an important explanation to why coalitions employ control mechanisms, such as, coalition agreements, focusing on the role of "preference tangentiality" as a predictor. "Preference tangentiality" among coalition partners is high when parties in a coalition have preferences that are not "overlapping," or when issues are of differing salience to the coalition partners. He suggests that when coalition parties are satisfied with a pure ministerial government model of policy making, and with "log-rolling policies," there are weaker incentives to implement control mechanisms. Looking at the existence of comprehensive coalition agreements, he finds support for this hypothesis.

In a recent study, Bowler et al. (2016) present a formal model aimed at understanding "the logic underlying the decision to adopt a coalition agreement and the choice to rely on procedural rules or dispute resolution mechanisms, rather than policy goals" (p. 1266). One of the main predictions that they derive is that the likelihood that the coalition agreement includes a dispute resolution mechanism increases when the level of intra-coalition conflict increases. They evaluate predictions drawn from their model using data on coalition agreements in the German Länder, analyzing two dependent variables, where the first describes whether the coalition agreement includes a dispute resolution mechanism, and the second variable captures the attention devoted to coalition management in the agreement. Their results show 
that when intra-coalition conflict is high, parties are more likely to include a dispute resolution mechanism in their coalition agreements. They also show that there seems to be a trade-off between such resolution mechanisms and writing lengthy policy statements, as these two features are negatively correlated (see Bowler et al., 2016, p. 1272).

To sum up, the previous literature has made important contributions by showing that coalition agreements affect policy making and conflict resolution. Moreover, some studies have focused on explaining the overall length of coalition agreements, relying primarily on the data set by Strøm and colleagues (2008). We here draw on these studies, but instead of focusing on overall length of agreements as a dependent variable, we suggest focusing on explaining "issue attention" across agreements, because parties involved in negotiating a coalition deal may have conflicting interests on some policy issues, but nonconflicting interests on other issues. In the next section, we present our theoretical expectations predicting issue attention.

\section{Theory and Hypotheses}

\section{Coalition Governance, Principal-Agent Theory, and the Role of Coalition Agreements}

To explain why the attention that coalition parties devote to different policy issues in coalition agreements varies, we draw on the literature on coalition governance, which takes its starting point in the so-called "parliamentary chain of delegation" that describes power relationships in parliamentary systems as a "chain," where (a) voters delegate power to representatives; (b) who, in turn, delegate power to a cabinet and a prime minister (PM); (c) who delegates power to line ministers within the cabinet; and (d) ministers, in their capacity as heads of department, in turn, delegate to civil servants (see, for example, Strøm, 2003; Strøm, Müller, \& Bergman, 2003). We here focus on the third step of the parliamentary chain of delegation, on how power is delegated to individual ministers, where several problems of "agency loss" may occur.

It has been suggested that the PM and the coalition leadership face a problem of adverse selection, because at the time of appointment, the PM does not have complete information about a minister's abilities and willingness to run a department effectively and in accordance with the wishes of the PM (see, for example, Kam, Bianco, Sened, \& Smyth, 2010). In addition, moral hazard problems can arise in this relationship because, as described by Indridason and Kam (2008) "all ministers have motive and opportunity to use their portfolios in a manner that runs against the PM's interests" (p. 624). One reason 
for "ministerial drift" specific to multiparty systems where coalition governments form is that ministers are likely to adhere to their party leaders rather than the collective goals of the coalition or the PM, because their party is an important principal to them, determining their reappointment and future electoral and career prospects (Andeweg, 2000; Bäck, Debus, \& Müller, 2016; Müller \& Meyer, 2010).

One way for coalition partners to structure policy making is to establish a "pure ministerial government" model (Laver \& Shepsle, 1996), where each party is allowed to implement its preferred policy in each departmental jurisdiction, and where no compromises are made between the parties within a policy area. However, as described by Indridason and Kristinsson (2013), "pure ministerial government results in Pareto inefficient policy outcomes" (p. 824)-alternative positions exist that the governing parties prefer to the positions implemented under pure ministerial government. In this sense, "agreements are intended to move issues away from their 'rightful' portfolios to the cabinet level (p. 824)."

Hence, an important instrument through which coalition parties can control their partners are coalition agreements, which put limits on ministers in terms of policy making, because such "contracts" establish what the ministers should do in office, thereby limiting problems of delegation. ${ }^{1}$ Although not every policy detail can be fixed ex ante, coalition agreements establish "reference points" about future policies, in particular, with regard to those issues that are contested between the partners. These reference points are important, as unclearly stated policies tend to produce different expectations among the partners about policy making during the course of the legislative term. If such expectations are not met, a party that considers that the agreement has not been upheld may choose to "retaliate" by also breaking the agreement in its policy jurisdictions, or may decide to leave the coalition, causing the government to fall. As most coalition agreements are public, reputational concerns clearly play a role, and publicity of the deal, thus, makes it costlier for parties to renege on their concessions and more likely to implement what is specified in the contract (Bäck et al., 2017).

More specifically, there are important office and electoral costs of not complying with the coalition agreement. With regard to political offices, not adhering to the negotiated compromise settled down in the agreement, typically results in intra-cabinet conflict and may ultimately lead to early cabinet breakdown, so that coalition parties would lose control over executive offices earlier than necessary. In addition, noncompliance with the coalition agreement may also have detrimental consequences for the future office prospects of coalition parties as possible future coalition partners will not risk cabinet stability by forming a coalition with unreliable parties. With regard to electoral 
costs, coalition partners will publicly blame a party for not complying with the negotiated coalition agreement and for risking the stability of the cabinet. As voters typically appreciate reliable parties, shirking from the negotiated agreement may result in significant electoral costs as parties can be publicly blamed as an unreliable coalition partner that jeopardizes cabinet stability and does not keep its promises.

\section{Hypotheses on Issue Attention in Coalition Agreements}

Having established that coalition agreements are important control devices to keep coalition partners in line, we are now turning to explaining variation across agreements. In this article, we focus on one explanatory feature that has been stressed in the previous literature, namely, "intra-coalition conflict" (see, for example, Indridason \& Kristinsson, 2013). Intra-coalition conflict implies a greater risk of ministerial drift-when there are large ideological differences in the coalition, ministers coming from specific parties are more likely to "stray" from the position of the coalition as a whole or the PM, simply because they do not agree with it. Hence, when ideological differences are large, ministers "left to their own devices" in a department are likely to implement their or their preferred party's policy position. This suggests that the potential policy benefits from drafting a coalition agreement are much larger when intra-cabinet conflict is high, and ideologically divided coalitions are, thus, more likely to write longer coalition agreements (Indridason \& Kristinsson, 2013, p. 828).

Going beyond the previous literature, we argue that not only it is the existence and the overall length of agreements that are affected by the degree of cabinet conflict but also the attention that is paid to specific policy issues is determined by issue divisiveness. This argument is based on the assumption that the level of detail devoted to a policy issue importantly affects the level of autonomy that ministers have in a policy area. Whereas an agreement that hardly discusses a policy area leaves considerable room of maneuver for the minister, agreements that entail a very detailed discussion of a policy area will determine the legislative agenda in that policy domain in much more detail, so that the minister has little autonomy in her jurisdiction. Or, in other words, higher attention to a policy issue in an agreement should constrain the coalition partners by prescribing in detail which policy proposals will be adopted.

Thus, as explained above, we argue that important variation within cabinets is overlooked by only looking at the existence and the overall length of an agreement as there may be consensus on some policy issues, but severe conflict over other issues in the cabinet. If there is no disagreement about an 
issue between cabinet members, coalition parties will not bother to spend a lot of time and effort on prescribing a detailed policy agenda, because coalition parties do not have to fear shirking by their partners. By contrast, if there is severe conflict over an issue between coalition members, parties will devote a lot of attention to the issue in the coalition agreement to settle a detailed policy agenda that leaves little room of maneuver for shirking. Thus, we hypothesize the following:

Hypothesis 1: The higher the intra-cabinet conflict over a policy issue, the higher the attention to the issue in the coalition agreement.

However, to predict issue attention, we suggest that it is not only important to specify how divisive specific issues are-we should also consider how important, or how salient, various policy issues are for the parties. As argued by Falcó-Gimeno (2014), when coalition parties are satisfied with a pure ministerial government model of policy making, and with "log-rolling policies," there are weaker incentives to implement control mechanisms. Or, differently put, such mechanisms are less necessary when "preference tangentiality" among coalition partners is high, or when issues are of differing salience to the coalition partners. Hence, when coalition partners do not care about the same policy issues, there is no need to come to a compromise on the issues, and coalition parties are happy with abdicating control over policy areas that they do not care about.

The argument is that because it is costly for the parties to negotiate and draft agreements, they may avoid such costs in situations when they do not have strong incentives to come to an agreement. The previous literature on coalition governance has stressed that there are "transaction costs" related to negotiating and drafting a coalition agreement, for example, because bargaining takes time and creates opportunity costs. Strøm and Müller (1999) suggest that complex bargaining situations heighten transaction costs, and, thus, predict that "high transaction costs lead to the adoption of less comprehensive agreements" (p. 276). Other potential costs are so-called "audience costs," resulting from the fact that parties have to make compromises with coalition partners when drafting agreements (Strøm, Müller, \& Smith, 2010, p. 529). ${ }^{2}$ Thus, when preference tangentiality is high, that is, when issues are of differing salience to the coalition partners, coalition partners do not engage in costly bargaining over the issues.

To clarify, let us give a hypothetical example of a two-party government including Parties A and B. We here assume that Party A has a strong interest in a Policy Area Z, that is, this policy area is highly salient for Party A. We also assume that Party B has very little interest in Policy Area Z, that is, Party 
A and Party B's preferences are clearly tangential here. In this situation, Party $\mathrm{B}$ may be satisfied with a pure ministerial government model when it comes to this policy issue, where Party A is given complete freedom to do as A pleases, becoming the Head of Department of Ministry Z. Here, Party B has no strong incentives to constrain the minister of Party A, and seeks to limit transaction costs by not negotiating and drafting text in the coalition agreement on this particular issue. For example, if a green party, emphasizing environmental issues in its program, coalesces with another party that does not place high salience on such issues (or issues affected by environmental policy), and is allocated the Ministry of Environment, the green party is likely to be given "free reign" in the ministry. Hence, because the parties have tangential preferences, the coalition parties do not need to engage in extensive negotiations over environmental issues, and, thereby, limit transaction costs.

The opposite situation arises when parties in a coalition have overlapping preferences, that is, if several partners have strong interests in the same particular policy area, or when tangentiality on an issue is low. ${ }^{3} \mathrm{Or}$, as Falcó-Gimeno (2014) puts it, “when partners' preferences overlap (i.e., they care enough about what happens in the jurisdictions controlled by the others in cabinet), the compromise deal is the one they prefer" (p. 345). In such a situation, it becomes worth it for the coalition partners to take on the transaction costs that come with drafting an agreement on this topic because they have strong incentives to limit agency loss in this policy area. Rather than abdicating control, coalition partners engage in "managed delegation" by constraining their partners through a detailed coalition agreement. Using a hypothetical example, assume that Parties A and B form a coalition, that they both significantly care about Policy Area $\mathrm{Y}$ and that Party A is given Ministry Y. In such a situation, Party B has strong incentives to try to control Party A's behavior, and will, therefore, devote time and energy to draft a very detailed section in the coalition agreement on Policy Area Y, prescribing in detail which policies will be enacted in that policy domain, to avoid that Party A shirks from the coalition compromise and implements its own position in Ministry Y. Following this line of argument, we suggest a conditional hypothesis:

Hypothesis 2: The higher the preference tangentiality among coalition parties, the weaker the positive effect of intra-cabinet conflict on attention to the issue in the coalition agreement.

Finally, we argue that the overall salience of a policy area importantly conditions the effects of intra-cabinet conflict and preference tangentiality. Not all issues are equally important to coalition parties as, for instance, sports are 
typically much less important than, for example, defense. Coalition parties may have diverging preferences on issues that are only of minor importance to them. Because coalition parties typically seek to avoid intra-cabinet conflict not to endanger cabinet stability, it is reasonable to expect that coalition parties are less inclined to risk cabinet conflict on an issue that is not important to them. We, therefore, expect that the negative effect of conflict as well as the conditioning effect of preference tangentiality are conditioned by the overall salience of the issue among coalition partners. Hence, if an issue is not important to any of the coalition parties, conflict and tangentiality should not matter. To clarify, if an issue is not salient to any of the coalition partners, it is reasonable to expect that neither the main effect of conflict, nor the conditioning effect of tangentiality is substantively important. We, therefore, hypothesize the following:

Hypothesis 3: The lower the joint salience of an issue, the smaller the effect of intra-cabinet conflict and the smaller the conditioning effect of preference tangentiality.

\section{Research Design and Data}

In this section, we explain our overall empirical strategy in more detail. We begin by outlining the case selection before we proceed to discussing the measurement of the dependent and independent variables. To evaluate our theoretical expectations explaining the issue attention in coalition agreements, we have compiled a new data set on the policy content of 224 coalition agreements negotiated by 181 political parties in 24 West and East European countries from 1945 until 2015. ${ }^{4}$ These countries include Austria, Belgium, Bulgaria, the Czech Republic, Denmark, Estonia, Finland, Germany, Greece, Hungary, Iceland, Ireland, Latvia, Lithuania, Luxembourg, the Netherlands, Norway, Poland, Portugal, Romania, Slovakia, Slovenia, Sweden, and the United Kingdom. The selection of countries follows the established standard in coalition research and only includes European democracies that were governed by coalition cabinets that have publicly released a coalition agreement at least once in the time period under investigation (see, for example, Andersson, Bergman, \& Ersson, 2014). This country sample is characterized by variation in several institutional features, which strengthens the external validity of our findings.

\section{A Novel Data Set on the Content of Coalition Agreements}

To measure the attention to different policy issues in coalition agreements, we rely on a novel and unprecedented data set on the content of coalition 
agreements. More precisely, we conducted a comprehensive analysis of coalition treaties that draws on human coders to analyze the content of coalition agreements. We have chosen to rely on a manually coded content analysis for a number of reasons. First, although fully automated quantitative text analysis techniques have the advantage to be $100 \%$ reliable and replicable, human coding is generally considered to be superior with regard to the validity of the measurement. In addition, statistical content analysis treats words as data and is, therefore, language sensitive. Given that we perform an analysis of coalition agreements applying the same coding scheme to agreements in 24 Western and Eastern European countries, human coding is more appropriate as the technique can be easily applied to texts in any language. Another important advantage of human coding is the compatibility with data on the content of election manifestos generated by the Manifestos Project (MP; Budge, Klingemann, Volkens, Bara, \& Tanenbaum, 2001; Klingemann, Volkens, Bara, Budge, \& McDonald, 2006; Volkens et al., 2017). This project developed a classification scheme with 56 categories grouped into seven policy domains.

To allow for matching the coalition agreement with the election manifesto data, we have conducted a content analysis largely following the coding procedure of the MP. More precisely, human coders with native language skills and country-specific expert knowledge divided the coalition agreements into units of analysis and then allocated each unit to one of the specified categories. Following the MP, we rely on so-called "quasi-sentences" as the unit of analysis (Klingemann et al., 2006, p. xxiii). To ensure compatibility with the election manifesto data, we have coded the coalition agreements based on an extended version of the MP codebook following the MP coding procedure and instructions. To guarantee the reliability of the coding, we have conducted extensive reliability tests and the average reliability based on the percent agreement amounts to $92 \%$, whereas the average Krippendorff's alpha is .89. Further information on the data collection process is provided in Appendix B.

\section{Operationalization of the Dependent and Main Independent Variables}

On the basis of this content analysis, we measure issue attention in coalition agreements by the percentage of quasi-sentences (positive and negative) in the coalition agreement devoted to a policy issue (see also Bäck, Debus, \& Dumont, 2011; Klüver \& Spoon, 2016; Spoon \& Klüver, 2014, 2015). ${ }^{5}$ The underlying rationale for using this approach is the following: A coalition 
agreement has a finite number of words that parties can use to express their stance on different policy issues. When drafting their coalition agreement, parties, therefore, have to decide how much attention they place on different issues, that is, how many words they will allocate to different policy domains. Devoting more attention to a policy issue necessarily includes a longer bargaining process about this issue as coalition parties typically settle on a much more detailed policy agenda in this issue area (Müller \& Strøm, 2008).

To test the effect of issue-specific cabinet conflict on the attention that is devoted to different policy issues in the coalition agreement, we rely on the election manifesto data provided by the abovementioned MP, computing issue-specific policy positions using the widely used additive percentage scores advocated by Budge (1999). ${ }^{6}$ The positions are estimated by calculating the percentages of positive and negative mentions of a policy issue, and then subtracting the percentage of negative mentions from the percentage of positive mentions of that issue. We identified 11 issue areas based on the MP for which the codebook includes positional categories, so that we can estimate not only the attention to the issue but also the issue-specific policy positions of the parties (see Table A1 in Appendix A for an overview of the issue areas and the associated MP categories). Second, following Tsebelis (2002), we then generated the range of the policy positions held by cabinet parties in the 11 issue areas to operationalize issue-specific cabinet conflict.

Our second hypothesis suggests that preference tangentiality decreases the positive effect of intra-cabinet conflict on issue attention in coalition agreements. Tangentiality refers to the relative salience of policy issues for coalition parties. Preferences of coalition parties are highly tangential if a policy issue is highly salient to one coalition party, but not salient to the coalition partners. We operationalize the tangentiality of coalition parties' preferences over a policy issue as follows. First, we measure the salience of a policy issue for all coalition parties by the relative number of quasi-sentences devoted to the issue in their respective election manifestos. Second, we compute the standard deviation of the issue-specific salience scores of all coalition parties. The standard deviation expresses the varying salience of a policy issue for the different coalition parties (see Falcó-Gimeno, 2014). The smaller the standard deviation, the larger the overlap of coalition parties' preferences as a policy issue is equally salient to all partners.

Our third hypothesis stresses the importance of the joint salience of the issue among coalition partners, which is expected to condition the impact of tangentiality and issue-specific cabinet conflict. We measure the joint salience of an issue by computing the salience of an issue to each coalition partner drawing on the relative number of quasi-sentences devoted to the issue in the 
coalition parties' election manifestos, and then computing the average of the salience of the issue across all cabinet parties.

\section{Operationalization of Control Variables}

To analyze the impact of intra-cabinet conflict, preference tangentiality, and joint issue salience, we control for several variables, which might potentially confound the hypothesized effects. First, we control for the effective number of parliamentary parties as more parties in parliament potentially provide more alternative coalition options for cabinet parties, and uncertainty increases with the number of parties in parliament. Tighter control mechanisms, such as detailed coalition agreements, are, therefore, more likely to prevent an early breakdown of the cabinet when coalition parties have potentially more alternative partners in a situation of greater uncertainty. Second, we control for the number of cabinet parties (Müller \& Strøm, 2008) because the number of parties involved in a multiparty cabinet may increase preference heterogeneity, so that coalition parties negotiate longer, more detailed agreements. Third, we also include a variable measuring the minority status of a coalition in the empirical analysis, as Indridason and Kristinsson (2013) show that minority status importantly affects the likelihood and the length of coalition agreements. Fourth, we also control for the minimal winning status of a cabinet as the incentives for comprehensive coalition agreements are higher because each party's contribution is necessary for the coalition's functioning (Müller \& Strøm, 2008). ${ }^{7}$

The data for measuring the effective number of parliamentary parties, the number of cabinet parties, and minority status are obtained from the ParlGov database (Döring, 2013; Döring \& Manow, 2016), whereas the minimal winning status was measured by relying on data gathered from the European Representative Democracy Dataset (Andersson et al., 2014). Descriptive statistics for all variables are presented in Table A2 in Appendix A.

\section{Empirical Analysis}

In this section, we will test our theoretical expectations based on the new data set we compiled. We first present some descriptive information about the attention that coalition parties devote to various policy issues in their coalition agreements. After this, we present the results of a multilevel regression analysis evaluating the impact of issue-specific cabinet conflict, preference tangentiality, and joint issue salience on issue attention in coalition agreements. 


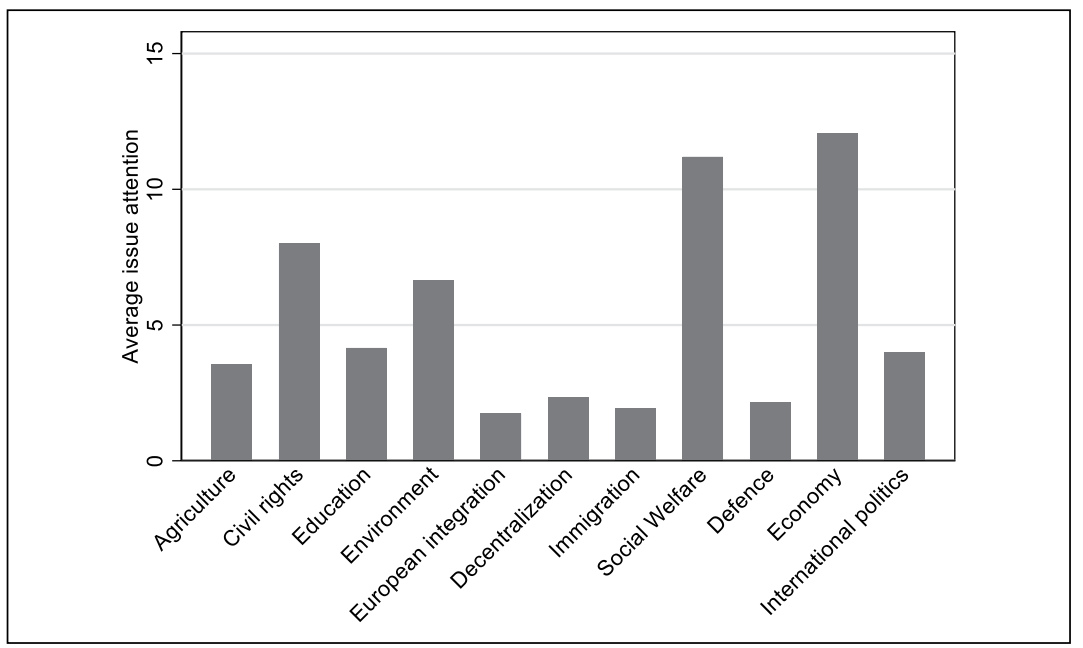

Figure I. Average issue attention (in \%).

\section{Descriptive Results of Policy Issue Attention in Coalition Agreements}

Figure 1 plots the average attention that coalition governments pay to different policy issues in their agreements across countries and over time. The policy issues that receive most attention in coalition contracts are the economy $(12.05 \%)$, social welfare $(11.20 \%)$, civil rights $(8.00 \%)$, and the environment $(6.66 \%)$. Economic policy, social welfare, and civil rights are clear positional issues on which political parties have very distinct policy positions, suggesting that coalition parties devote a lot of attention to potentially divisive policy issues. The environment is, by contrast, a valence issue, but given that the emergence of green parties challenging established mainstream parties is strongly associated with the rise of the environmental issue, it is not surprising that this issue also triggers a lot of attention.

By contrast, policy issues that are only moderately covered in the coalition agreements are agriculture (3.55\%), education $(4.16 \%)$, and international politics $(3.98 \%)$, which are issues that are typically not "owned" by any particular party, ${ }^{8}$ and are issues on which government parties are typically not particularly polarized. Least attention received European integration (1.75\%), decentralization (2.34\%), defense $(2.14 \%)$, and immigration $(1.94 \%)$. Although European integration, defense, and decentralization are policy issues that are usually not very divisive among government parties in most 


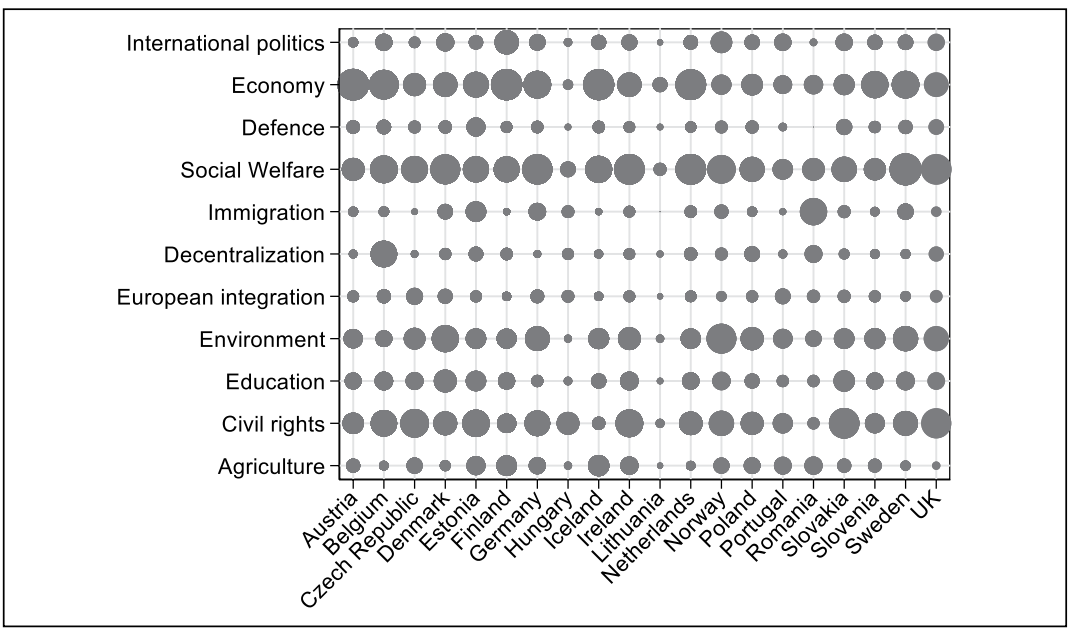

Figure 2. Issue attention across countries.

European democracies, at least until recently, the comparatively low level of attention to immigration is surprising and may be due to some overlap with the civil rights issue area.

To gain some understanding as to how issue attention varies across countries, Figure 2 plots the average attention that coalition parties in the different countries in our sample pay to various policy issues in their coalition agreements. The larger the circle, the higher the attention to the specific policy issue. Overall, this figure confirms the aggregated picture as the economy, social welfare, civil rights, and the environment are policy issues that generally receive a lot of attention across countries, whereas other issues, such as European integration, defense, or decentralization generally receive very little coverage in the coalition agreements. However, there is some variation across countries, for example, the issue attention in Lithuania is generally very low compared with the other countries. This is explained by the fact that Lithuanian coalition cabinets primarily focus on conflict resolution mechanisms in their coalition agreements, while hardly including any policy commitments in their coalition treaty.

\section{Multivariate Results Predicting Issue Attention in Coalition Agreements}

In the next step, we evaluate our theoretical expectations based on a multivariate regression analysis. Our data are hierarchically structured, as the 
coalition agreements in our sample are negotiated by cabinet parties in 24 different countries. Given that these countries vary extensively with regard to their electoral system, the structure of the party system, and their experience with coalition governance, coalition cabinets in the same country face the same contextual characteristics that are different from those in other countries. Estimating an ordinary linear regression model on the basis of such a data structure may result in deflated standard errors and inflated type I error rates, so the significance of estimated effects may be overrated (Steenbergen \& Jones, 2002, pp. 219-220). To model this particular data structure, we rely on a multilevel linear regression model that takes the clustering of cabinets in countries into account by allowing for residual components at the country level. ${ }^{9}$ Given that the dependent variable measures the attention that parties pay to 11 different policy issues in their agreements, we have also estimated an alternative model specification that additionally includes issue-specific fixed effects to account for any issue-specific variance in our data (see Table A3 in Appendix A). As the results are substantially the same, we rely on the more parsimonious model specification presented in Table 1.

Table 1 presents the results of the multilevel linear regression analysis. Model 1 includes all main effects as well as the interaction effect between conflict and preference tangentiality, whereas Model 2 additionally includes a three-way interaction effect between conflict, preference tangentiality, and joint salience. In line with Hypothesis 1, the regression analysis shows that issue-specific cabinet conflict has a statistically significant positive effect on the attention that coalition parties pay to policy issues in their agreements. Hence, coalition parties talk more extensively in their treaty about the issues that divide them. If coalition partners have strongly diverging preferences on an issue, they choose to spell out the policy agenda in this issue area in great detail to leave as little room of maneuver as possible to their partners. The more detailed the description of the policy proposals that will be enacted, the smaller the potential for shirking or "ministerial drift."

To further illustrate the effect of issue-specific cabinet conflict on the attention that coalition parties pay to different policy issues in their coalition agreement, we have simulated predicted values as suggested by King, Tomz, and Wittenberg (2000). Figure 3 plots the simulated predicted issue attention $(y$ axis), as intra-cabinet conflict over policy issue varies ( $x$ axis), while holding all control variables constant at their mean (continuous variables) and median (categorical variables) values. The solid line represents the predicted values and the dashed lines indicate the $95 \%$ confidence interval. The tick marks along the $x$ axis indicate the distribution of the conflict variable. Figure 3 clearly shows that the attention that is devoted to policy issues in the coalition agreement increases substantially with the ideological conflict among 
Table I. Results From Multilevel Linear Regression.

\begin{tabular}{|c|c|c|}
\hline $\begin{array}{l}\text { Dependent variable: Issue attention in coalition } \\
\text { agreements }\end{array}$ & Model I & Model 2 \\
\hline \multicolumn{3}{|l|}{ Fixed effects } \\
\hline \multirow[t]{2}{*}{ Issue-specific cabinet conflict } & $0.281 * * *$ & $0.283^{* * *}$ \\
\hline & $(0.032)$ & $(0.067)$ \\
\hline \multirow[t]{2}{*}{ Preference tangentiality } & -0.006 & -0.120 \\
\hline & $(0.06 I)$ & $(0.127)$ \\
\hline \multirow[t]{2}{*}{ Joint salience } & $0.488 * * *$ & $0.566 * * *$ \\
\hline & $(0.022)$ & $(0.033)$ \\
\hline \multirow[t]{2}{*}{ Effective number of parliamentary parties } & $0.207^{*}$ & $0.209 *$ \\
\hline & $(0.126)$ & $(0.125)$ \\
\hline \multirow[t]{2}{*}{ Number of cabinet parties } & $-0.298 *$ & $-0.292 *$ \\
\hline & $(0.163)$ & $(0.164)$ \\
\hline \multirow[t]{2}{*}{ Minority status } & 0.294 & 0.281 \\
\hline & $(0.397)$ & $(0.396)$ \\
\hline \multirow[t]{2}{*}{ Minimal winning status } & 0.461 & 0.478 \\
\hline & $(0.299)$ & $(0.298)$ \\
\hline \multirow{2}{*}{$\begin{array}{l}\text { Issue-specific cabinet conflict } \times \text { Preference } \\
\text { tangentiality }\end{array}$} & $-0.017 * * *$ & -0.001 \\
\hline & $(0.002)$ & $(0.006)$ \\
\hline \multirow[t]{2}{*}{ Issue-specific cabinet conflict $\times$ Joint salience } & & -0.007 \\
\hline & & $(0.004)$ \\
\hline \multirow[t]{2}{*}{ Preference tangentiality $\times$ Joint salience } & & -0.002 \\
\hline & & $(0.008)$ \\
\hline \multirow{2}{*}{$\begin{array}{l}\text { Conflict } \times \text { Preference tangentiality } \times \text { Joint } \\
\text { salience }\end{array}$} & & -0.000 \\
\hline & & $(0.000)$ \\
\hline \multirow[t]{2}{*}{ Constant } & 0.734 & 0.565 \\
\hline & $(0.662)$ & $(0.678)$ \\
\hline \multicolumn{3}{|l|}{ Random effects } \\
\hline \multirow[t]{2}{*}{ Country-level variance } & 0.967 & 0.983 \\
\hline & $(0.401)$ & $(0.403)$ \\
\hline \multirow[t]{2}{*}{ Cabinet-level variance } & 20.704 & 20.569 \\
\hline & $(0.593)$ & $(0.589)$ \\
\hline$N$ & 2,464 & 2,464 \\
\hline Log likelihood & $-7,248$ & $-7,240$ \\
\hline Akaike information criterion & $14,5 \mid 8$ & 14,509 \\
\hline
\end{tabular}

$*_{p}<.10 .{ }^{* *} p<.05 . *^{* *} p<.01$.

coalition partners. The larger the conflict over an issue among coalition parties, the more attention they devote to this issue in their coalition agreements. 


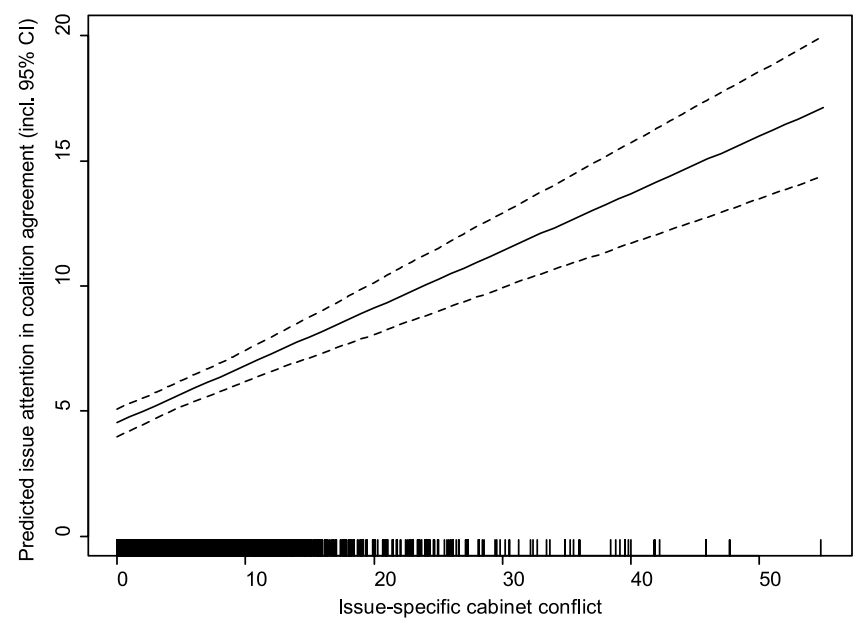

Note: The figure is based on model 1.

Figure 3. The effect of intra-cabinet conflict.

The figure is based on Model I.

Turning to evaluate our second hypothesis, we ask whether the effect of intra-cabinet conflict varies depending on the tangentiality of different issues. In line with Hypothesis 2, the empirical analysis indicates that preference tangentiality conditions the effect of intra-cabinet conflict. More specifically, Model 1 shows that there is a statistically significant negative interaction effect, suggesting that the positive effect of conflict decreases as preference tangentiality increases. In other words, intra-coalition conflict seems to matter a great deal when preference tangentiality is low, that is, when all coalition partners equally care about a policy issue. If that is the case, all coalition partners have strong incentives to "bind" their coalition partners by spelling out the policy agenda in great detail, to make sure there is no room of maneuver left for their partners to defect from the compromise. By contrast, if preference tangentiality is high, that is, if one coalition party cares a lot about an issue, whereas its partners are largely indifferent to the issue, parties talk less about the issue. To further illustrate the conditioning effect of preference tangentiality, we have computed a marginal effects plot (see Brambor, Clark, \& Golder, 2006). Figure 4 shows the marginal effect of issue-specific intracabinet conflict on issue attention in coalition agreements as preference tangentiality varies. The solid line indicates the point estimates of the marginal 


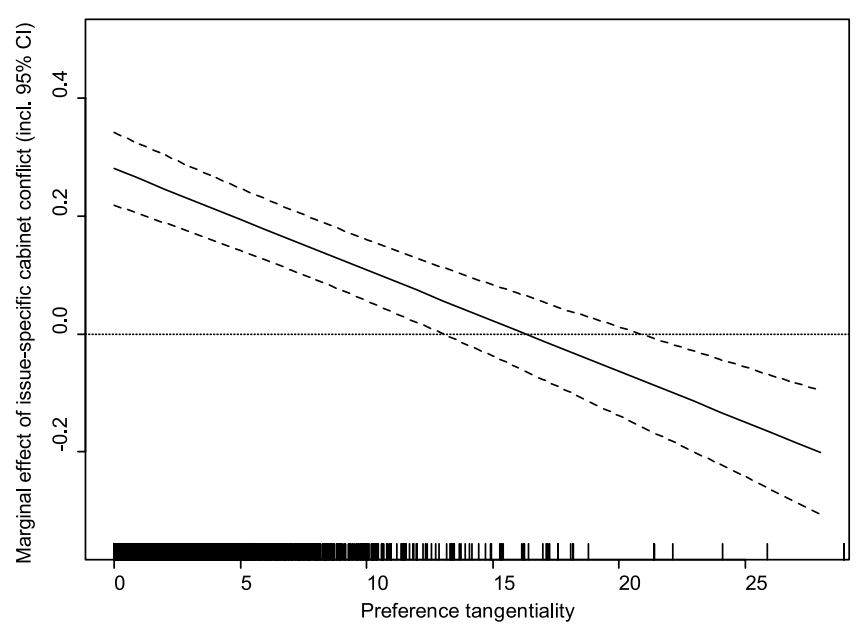

Note: The figure is based on model 1.

Figure 4. The conditioning effect of tangentiality.

The figure is based on Model I.

effect, whereas the dashed lines indicate the $95 \%$ confidence interval. The figure clearly demonstrates that the positive effect of intra-cabinet conflict over policy issues on the attention paid to these issues in the coalition agreement declines as preference tangentiality rises.

Finally, to empirically assess whether the joint salience of a policy issue has an effect on the attention to the issue in the coalition agreement, we have estimated a second model that includes a three-way interaction effect between intra-cabinet conflict, tangentiality, and joint salience (see Model 2 in Table 1). Although the coefficient of the three-way interaction term is statistically insignificant in Model 2, it is possible that the marginal effect of conflict is significant for substantively relevant values of the modifying variables (Brambor et al., 2006, p. 74).$^{10}$ We have, therefore, computed a marginal effects plot on the basis of Model 2 to investigate how the effect of intracabinet conflict varies with tangentiality and the joint salience of an issue among cabinet parties as recommended by Brambor et al. (2006).

Figure 5 shows the marginal effect of cabinet conflict on issue attention in the coalition agreement as tangentiality varies from its minimum to maximum value for different values of joint salience. The solid lines indicate the point estimates of the marginal effects, whereas the stars indicate the 


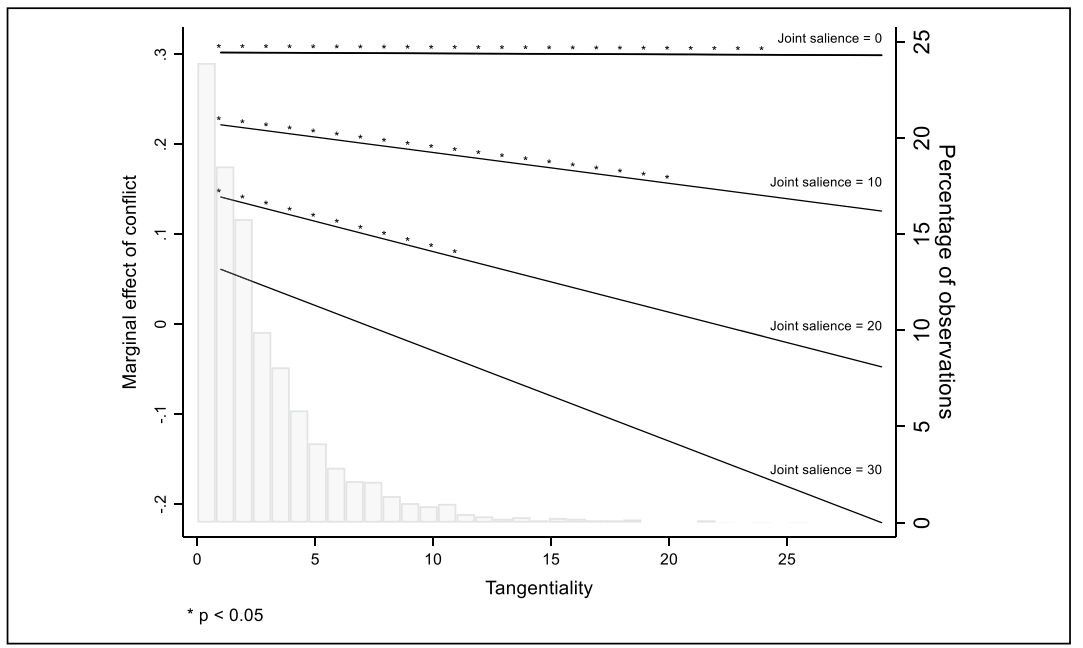

Figure 5. Three-way interaction between conflict, tangentiality, and joint salience. The figure is based on Model 2.

statistical significance of the marginal effects. The figure demonstrates that the marginal effect of conflict declines with tangentiality, whereas it increases with the joint salience of an issue among coalition partners.

To sum up our results, analyzing the variation of policy issue attention across coalition agreements, our hypotheses are supported. We find that the higher the intra-cabinet conflict over a policy issue, the higher the attention to the issue in the coalition agreement. However, the effect of cabinet conflict is clearly conditional on preference tangentiality and the overall salience of the issue within the cabinet as the effect of conflict declines with tangentiality, whereas it increases with the joint salience of an issue among coalition partners.

\section{Conclusion}

Why do coalition parties settle some policy issues in great detail, thus prescribing a detailed policy agenda, whereas other issues are hardly mentioned in coalition agreements? This article has focused on answering this question by explaining variation in the content of coalition agreements presented in parliamentary democracies. Our theoretical starting point was that parties have clear incentives in bearing the costs of negotiating an agreement on specific policy issues, especially when ideological divisiveness among 
coalition partners on issues is high. In such situations, we theorized, coalition partners will draft coalition agreements covering divisive issues at length to limit "ministerial drift," to avoid that coalition partners deviate from the coalition position when given power over a specific department. However, we also theorized that they should only do so when all included coalition partners care about the specific policy issue, that is, when preference tangentiality is low and joint salience is high.

Using a new and unique data set on the content of 224 coalition agreements in 24 West and East European countries drafted by coalition governments formed during the postwar period, we find support for our expectations. We find that political parties are clearly more likely to focus extensively on a specific policy issue in the coalition agreement when the coalition partners cannot agree on it. Hence, this supports the idea that coalition partners negotiate agreements to limit potential "agency loss" when delegating power to individual ministers in specific departments. We also find that the impact of intra-cabinet conflict on the attention given to an issue in the coalition agreement is weaker when joint salience is low and when preference tangentiality is high, that is, when the parties in government do not place equal salience on an issue. In such cases, it seems that ministers from different parties are allowed a high degree of "autonomy," or freedom to implement their preferred policy, as the coalition partners do not particularly care about the specific policy issue. Hence, our results show clear support for a coalition governance model, suggesting that parties draft agreements to limit delegation problems.

Although this study has provided important insights for our understanding of cabinet formation and coalition governance, much remains to be done. One of the potential problems of our approach, and the approach by most other scholars focusing on coalition agreements, is that coalition partners not only bargain about the policy priorities that guide legislative activity in the upcoming term but also simultaneously negotiate the division of ministerial posts. This means that coalition partners may strike package deals that cut across the division of ministerial posts and the agreement of policy priorities, so that ministerial posts might be exchanged for a commitment to a particular policy reform and vice versa. Thus, it may be argued that payoff allocation in coalition negotiations should be conceptualized as a two-dimensional process in which the allocation of ministerial portfolios cannot be treated independently from direct policy payoff allocation (Linhart \& Pappi, 2009; Shikano $\&$ Linhart, 2010). For simplicity, we have not taken the distribution of portfolios into account here, but in future research, we aim to analyze the potential trade-offs between portfolio and policy payoffs for political parties when they negotiate a coalition deal (see also Bäck et al., 2011). Similarly, another 
avenue for future research is investigating draft agreements of both coalitions that have successfully formed and draft agreements of potential coalitions whose negotiations have eventually failed to shed further light on the negotiation process and the factors that lead to successful coalition formation.

\section{Appendix A}

\section{Additional Tables}

Table AI. Areas based on Comparative Manifesto Project (CMP) Policy Categories.

\begin{tabular}{|c|c|c|c|}
\hline Issue area & CMP policy categories & Left position & Right position \\
\hline \multirow[t]{3}{*}{ Agriculture } & $\begin{array}{l}\text { 406: Protectionism } \\
\text { (positive) }\end{array}$ & $\begin{array}{l}\text { 406: Protectionism } \\
\text { (positive) }\end{array}$ & $\begin{array}{l}\text { 407: Protectionism } \\
\text { (negative) }\end{array}$ \\
\hline & $\begin{array}{l}\text { 407: Protectionism } \\
\text { (negative) }\end{array}$ & 703: Farmers & \\
\hline & $\begin{array}{l}\text { 703: Agriculture and } \\
\text { farmers (positive) }\end{array}$ & & \\
\hline \multirow[t]{7}{*}{ Civil rights } & $\begin{array}{l}20 \mathrm{I} \text { : Freedom and human } \\
\text { rights }\end{array}$ & $\begin{array}{l}\text { 20I: Freedom and } \\
\text { human rights }\end{array}$ & $\begin{array}{l}\text { 603: Traditional } \\
\text { morality (positive) }\end{array}$ \\
\hline & 202: Democracy & 202: Democracy & $\begin{array}{l}\text { 605: Law and order } \\
\text { (positive) }\end{array}$ \\
\hline & $\begin{array}{l}\text { 603: Traditional morality } \\
\text { (positive) }\end{array}$ & $\begin{array}{l}\text { 604: Traditional } \\
\text { morality (negative) }\end{array}$ & \\
\hline & $\begin{array}{l}\text { 604: Traditional morality } \\
\text { (negative) }\end{array}$ & $\begin{array}{l}\text { 705: Underprivileged } \\
\text { minority groups }\end{array}$ & \\
\hline & 605: Law and order & $\begin{array}{l}\text { 706: Noneconomic } \\
\text { demographic groups }\end{array}$ & \\
\hline & $\begin{array}{l}\text { 705: Underprivileged } \\
\text { minority groups }\end{array}$ & & \\
\hline & $\begin{array}{l}\text { 706: Noneconomic } \\
\text { demographic groups }\end{array}$ & & \\
\hline \multirow[t]{2}{*}{ Education } & 506: Education expansion & $\begin{array}{l}\text { 506: Education } \\
\text { expansion }\end{array}$ & $\begin{array}{l}\text { 507: Education } \\
\text { limitation }\end{array}$ \\
\hline & 507: Education limitation & & \\
\hline \multirow[t]{3}{*}{ Environment } & $\begin{array}{l}\text { 416: Antigrowth economy } \\
\text { (positive) }\end{array}$ & $\begin{array}{l}\text { 416: Antigrowth } \\
\text { economy (positive) }\end{array}$ & $\begin{array}{l}\text { 410: Economic growth } \\
\text { (positive) }\end{array}$ \\
\hline & $\begin{array}{l}\text { 50I: Environmental } \\
\text { protection }\end{array}$ & $\begin{array}{l}\text { 50I: Environmental } \\
\text { protection }\end{array}$ & \\
\hline & $\begin{array}{l}\text { 410: Economic growth } \\
\text { (positive) }\end{array}$ & & \\
\hline \multirow{2}{*}{$\begin{array}{l}\text { European } \\
\text { integration }\end{array}$} & I08: EC/EU (positive) & I08: EC/EU (positive) & I I0: EC/EU (negative) \\
\hline & I I0: EC/EU (negative) & & \\
\hline \multirow[t]{2}{*}{ Decentralization } & 30I: Decentralization & 30I: Decentralization & 302: Centralization \\
\hline & 302: Centralization & & \\
\hline
\end{tabular}


Table AI. (continued)

\begin{tabular}{|c|c|c|c|}
\hline Issue area & CMP policy categories & Left position & Right position \\
\hline \multirow[t]{4}{*}{ Immigration } & $\begin{array}{l}\text { 60I: National way of life } \\
\text { (positive) }\end{array}$ & $\begin{array}{l}\text { 602: National way of } \\
\text { life (negative) }\end{array}$ & $\begin{array}{l}\text { 60I: National way of } \\
\text { life (positive) }\end{array}$ \\
\hline & $\begin{array}{l}\text { 602: National way of life } \\
\text { (negative) }\end{array}$ & $\begin{array}{l}\text { 607: Multiculturalism } \\
\text { (positive) }\end{array}$ & $\begin{array}{l}\text { 608: Multiculturalism } \\
\text { (negative) }\end{array}$ \\
\hline & $\begin{array}{l}\text { 607: Multiculturalism } \\
\text { (positive) }\end{array}$ & & \\
\hline & $\begin{array}{l}\text { 608: Multiculturalism } \\
\text { (negative) }\end{array}$ & & \\
\hline \multirow[t]{3}{*}{ Social welfare } & 503: Equality (positive) & 503: Equality (positive) & $\begin{array}{l}\text { 505: Welfare state } \\
\text { limitation }\end{array}$ \\
\hline & $\begin{array}{l}\text { 504: Welfare state } \\
\text { expansion }\end{array}$ & $\begin{array}{l}\text { 504: Welfare state } \\
\text { expansion }\end{array}$ & \\
\hline & $\begin{array}{l}\text { 505: Welfare state } \\
\text { limitation }\end{array}$ & & \\
\hline \multirow[t]{2}{*}{ Defense } & I04: Military (positive) & I05: Military (negative) & 104: Military (positive) \\
\hline & 105: Military (negative) & & \\
\hline \multirow[t]{8}{*}{ Economy } & 40I: Free market economy & 403: Market regulation & $\begin{array}{l}\text { 40I: Free market } \\
\text { economy }\end{array}$ \\
\hline & 402: Incentives & 404: Economic planning & $\begin{array}{l}\text { 402: Incentives } \\
\text { (positive) }\end{array}$ \\
\hline & 403: Market regulation & $\begin{array}{l}\text { 409: Keynesian demand } \\
\text { management }\end{array}$ & $\begin{array}{l}\text { 4I4: Economic } \\
\text { orthodoxy }\end{array}$ \\
\hline & 404: Economic planning & $\begin{array}{l}\text { 4I2: Controlled } \\
\text { economy }\end{array}$ & \\
\hline & $\begin{array}{l}\text { 409: Keynesian demand } \\
\text { management }\end{array}$ & 413: Nationalization & \\
\hline & 412: Controlled economy & & \\
\hline & 4/3: Nationalization & & \\
\hline & 4I4: Economic orthodoxy & & \\
\hline \multirow[t]{6}{*}{$\begin{array}{l}\text { International } \\
\text { politics }\end{array}$} & $\begin{array}{l}\text { I0I: Foreign and special } \\
\text { relations (positive) }\end{array}$ & $\begin{array}{l}\text { I0I: Foreign and } \\
\text { special relations } \\
\text { (positive) }\end{array}$ & $\begin{array}{l}\text { 102: Foreign and } \\
\text { special relations } \\
\text { (negative) }\end{array}$ \\
\hline & $\begin{array}{l}\text { 102: Foreign and special } \\
\text { relations (negative) }\end{array}$ & 103: Anti-imperialism & $\begin{array}{l}\text { 109: Internationalism } \\
\text { (negative) }\end{array}$ \\
\hline & $\begin{array}{l}\text { 103: Anti-imperialism } \\
\text { (positive) }\end{array}$ & 106: Peace & \\
\hline & 106: Peace (positive) & $\begin{array}{l}\text { 107: Internationalism } \\
\text { (positive) }\end{array}$ & \\
\hline & $\begin{array}{l}\text { 107: Internationalism } \\
\text { (positive) }\end{array}$ & & \\
\hline & $\begin{array}{l}\text { 109: Internationalism } \\
\text { (negative) }\end{array}$ & & \\
\hline
\end{tabular}

$E C=$ European Communities. 
Table A2. Descriptive Statistics.

\begin{tabular}{lccccc}
\hline Variable & $N$ & $M$ & $S D$ & Min & Max \\
\hline Issue attention & 2,464 & 5.251 & 5.755 & 0.000 & 56.944 \\
Issue-specific cabinet conflict & 2,464 & 5.765 & 6.753 & 0.000 & 54.756 \\
Preference tangentiality & 2,464 & 2.911 & 3.224 & 0.000 & 28.930 \\
Joint salience & 2,464 & 6.268 & 5.941 & 0.000 & 34.964 \\
Effective number of parliamentary & 2,464 & 4.579 & 1.337 & 2.195 & 9.051 \\
$\quad$ parties & & & & & \\
Number of cabinet parties & 2,464 & 3.018 & 1.086 & 2.000 & 6.000 \\
Minority status & 2,464 & 0.156 & 0.361 & 0.000 & 1.000 \\
Minimal winning status & 2,464 & 0.571 & 0.495 & 0.000 & 1.000 \\
\hline
\end{tabular}

Table A3. Results From Multilevel Linear Regression With Issue Fixed Effects.

\begin{tabular}{lcc}
\hline $\begin{array}{l}\text { Dependent variable: Issue attention in } \\
\text { coalition agreements }\end{array}$ & Model 3 & Model 4 \\
\hline Fixed effects & & \\
Issue-specific cabinet conflict & $0.204^{* * * *}$ & $0.213^{* * * *}$ \\
& $(0.030)$ & $(0.063)$ \\
Preference tangentiality & -0.026 & $-0.225^{*}$ \\
& $(0.057)$ & $(0.120)$ \\
Joint salience & $0.255^{* * * *}$ & $0.280^{* * *}$ \\
& $(0.027)$ & $(0.038)$ \\
Effective number of parliamentary parties & $0.196^{*}$ & 0.195 \\
& $(0.119)$ & $(0.118)$ \\
Number of cabinet parties & $-0.259^{*}$ & $-0.264^{*}$ \\
& $(0.153)$ & $(0.154)$ \\
Minority status & 0.273 & 0.262 \\
& $(0.373)$ & $(0.373)$ \\
Minimal winning status & 0.430 & 0.433 \\
& $(0.280)$ & $(0.279)$ \\
Issue-specific cabinet conflict $\times$ Preference & $-0.010^{* * * *}$ & 0.005 \\
tangentiality & $(0.002)$ & $(0.006)$ \\
Issue-specific cabinet conflict $\times$ Joint & & -0.004 \\
salience & & $(0.004)$ \\
Preference tangentiality $\times$ Joint salience & & 0.010 \\
& & $(0.008)$ \\
Conflict $\times$ Preference tangentiality $\times$ Joint & & $-0.001 * * *$ \\
salience & & $(0.000)$ \\
\hline
\end{tabular}


Table A3. (continued)

\begin{tabular}{lcc}
$\begin{array}{l}\text { Dependent variable: Issue attention in } \\
\text { coalition agreements }\end{array}$ & Model 3 & Model 4 \\
\hline Constant & $1.32 I^{*}$ & $\begin{array}{c}1.407^{* *} \\
(0.712)\end{array}$ \\
Random effects & $(0.694)$ & 1.180 \\
Country-level variance & 1.186 & $(0.446)$ \\
& $(0.449)$ & 17.858 \\
Cabinet-level variance & 17.924 & $(0.511)$ \\
$N$ & $(0.513)$ & 2,464 \\
Log likelihood & 2,464 & $-7,069$ \\
Akaike information criterion & $-7,074$ & 14,186 \\
\hline
\end{tabular}

Fixed effects for issue areas are not reported.

$*_{p}<.10 . *_{p}<.05$. ***p $<.01$.

Table A4. Results From Multilevel Linear Regression With Policy-Related Issue Attention as the Dependent Variable.

\begin{tabular}{lcc}
\hline $\begin{array}{l}\text { Dependent variable: Issue attention in } \\
\text { coalition agreements }\end{array}$ & Model 5 & Model 6 \\
\hline Fixed effects & & \\
Issue-specific cabinet conflict & $0.299^{* * *}$ & $0.299^{* * *}$ \\
& $(0.035)$ & $(0.074)$ \\
Preference tangentiality & 0.004 & -0.132 \\
& $(0.067)$ & $(0.139)$ \\
Joint salience & $0.534^{* * *}$ & $0.628^{* * *}$ \\
& $(0.024)$ & $(0.037)$ \\
Effective number of parliamentary parties & 0.213 & 0.216 \\
& $(0.137)$ & $(0.137)$ \\
Number of cabinet parties & -0.294 & -0.284 \\
& $(0.179)$ & $(0.180)$ \\
Minority status & 0.409 & 0.394 \\
& $(0.435)$ & $(0.433)$ \\
Minimal winning status & 0.499 & 0.521 \\
& $(0.328)$ & $(0.327)$ \\
Issue-specific cabinet conflict $\times$ Preference & $-0.019 * * *$ & 0.002 \\
tangentiality & $(0.003)$ & $(0.007)$ \\
Issue-specific cabinet conflict $\times$ Joint & & $-0.008^{*}$ \\
salience & & $(0.005)$ \\
\hline
\end{tabular}




\section{Table A4. (continued)}

Dependent variable: Issue attention in coalition agreements

Model 5

Model 6

Preference tangentiality $\times$ Joint salience

$-0.002$

Conflict $\times$ Preference tangentiality $\times$ Joint salience

Constant

0.785

$(0.718)$

$(0.735)$

Random effects

Country-level variance

Cabinet-level variance

N

$(0.721)$

Log likelihood

Akaike information criterion

The dependent variable was calculated solely on the basis of policy-related quasi-sentences included in coalition agreements. Quasi-sentences related to procedure rules or that concern neither policies nor procedural rules were removed before calculating the percentage of quasi-sentences concerning a given policy issue.

$*_{p}<.10 .{ }^{* *} p<.05$. ***p $<.01$.

Table A5. Results From Multilevel Linear Regression With Cabinet Type as Control Variable.

Dependent variable: Issue attention in coalition agreements

Model 7

Model 8

\begin{tabular}{lcc}
\hline Fixed effects & & \\
Issue-specific cabinet conflict & $0.28 I^{* * *}$ & $0.283^{* * * *}$ \\
& $(0.032)$ & $(0.067)$ \\
Preference tangentiality & -0.006 & -0.120 \\
& $(0.061)$ & $(0.127)$ \\
Joint salience & $0.488^{* * *}$ & $0.566^{* * *}$ \\
& $(0.022)$ & $(0.033)$ \\
Effective number of parliamentary parties & $0.207^{*}$ & $0.209^{*}$ \\
& $(0.126)$ & $(0.125)$ \\
Number of cabinet parties & $-0.298^{*}$ & $-0.292^{*}$ \\
& $(0.163)$ & $(0.164)$ \\
Minimal winning status (reference: minority & 0.167 & 0.198 \\
status) & $(0.321)$ & $(0.320)$ \\
\hline
\end{tabular}


Table A5. (continued)

\begin{tabular}{lcc}
\hline $\begin{array}{l}\text { Dependent variable: Issue attention in coalition } \\
\text { agreements }\end{array}$ & Model 7 & Model 8 \\
\hline Surplus status (reference: minority status) & -0.294 & -0.281 \\
& $(0.397)$ & $(0.396)$ \\
Issue-specific cabinet conflict $\times$ Preference & $-0.017 * * *$ & -0.001 \\
tangentiality & $(0.002)$ & $(0.006)$ \\
Issue-specific cabinet conflict $\times$ Joint salience & & -0.007 \\
& & $(0.004)$ \\
Preference tangentiality $\times$ Joint salience & & -0.002 \\
& & $(0.008)$ \\
Conflict $\times$ Preference tangentiality $\times$ Joint & & -0.000 \\
salience & & $(0.000)$ \\
Constant & $1.028 *$ & 0.846 \\
& $(0.618)$ & $(0.635)$ \\
Random effects & & \\
Country-level variance & 0.967 & 0.983 \\
Cabinet-level variance & $(0.401)$ & $(0.403)$ \\
$N$ & 20.704 & 20.569 \\
Log likelihood & $(0.593)$ & $(0.589)$ \\
Akaike information criterion & 2,464 & 2,464 \\
\hline
\end{tabular}

${ }^{*} p<.10 .{ }^{* *} p<.05 . * * * p<.01$.

Table A6. Results From Multilevel Tobit Regression.

\begin{tabular}{lcc}
\hline $\begin{array}{l}\text { Dependent variable: Issue attention in } \\
\text { coalition agreements }\end{array}$ & Model 9 & Model I0 \\
\hline Fixed effects & $0.28 I^{* * * *}$ & $0.283^{* * *}$ \\
Issue-specific cabinet conflict & $(0.032)$ & $(0.067)$ \\
& -0.006 & -0.120 \\
Preference tangentiality & $(0.061)$ & $(0.127)$ \\
& $0.488^{* * *}$ & $0.566^{* * *}$ \\
Joint salience & $(0.022)$ & $(0.033)$ \\
& $0.207^{*}$ & $0.209^{*}$ \\
Effective number of parliamentary & $(0.126)$ & $(0.126)$ \\
parties & $-0.298^{*}$ & $-0.292^{*}$ \\
Number of cabinet parties & $(0.163)$ & $(0.164)$ \\
\hline
\end{tabular}




\section{Table A6. (continued)}

\begin{tabular}{lcc}
\hline Dependent variable: Issue attention in & Model 9 & Model I0 \\
coalition agreements & 0.294 & 0.281 \\
\hline Minority status & $(0.400)$ & $(0.399)$ \\
& 0.461 & 0.478 \\
Minimal winning status & $(0.300)$ & $(0.300)$ \\
& $-0.017^{* * *}$ & -0.001 \\
Issue-specific cabinet conflict $\times$ & $(0.002)$ & $(0.006)$ \\
Preference tangentiality & & -0.007 \\
Issue-specific cabinet conflict $\times$ Joint & & $(0.004)$ \\
salience & & -0.002 \\
Preference tangentiality $\times$ Joint & & $(0.008)$ \\
salience & & -0.000 \\
Conflict $\times$ Preference tangentiality & $0.000)$ \\
$\quad \times$ Joint salience & 0.734 & 0.565 \\
Constant & $(0.667)$ & $(0.683)$ \\
& & \\
Random effects & $0.967^{* *}$ & $0.982^{* *}$ \\
Country-level variance & $(0.401)$ & $(0.403)$ \\
& $20.704^{* * *}$ & $20.569^{* * *}$ \\
Cabinet-level variance & $(0.593)$ & $(0.589)$ \\
& 2,464 & 2,464 \\
$N$ & $-7,248$ & $-7,240$ \\
Log likelihood & 14,518 & 14,509 \\
Akaike information criterion & &
\end{tabular}

$* p<.10 . * * p<.05 . * * p p<.01$.

Table A7. Results From Multilevel Linear Regression With Cabinet Conflict Generated Using Chapel Hill Expert Survey Data.

\begin{tabular}{lcc}
$\begin{array}{l}\text { Dependent variable: Issue attention in } \\
\text { coalition agreements }\end{array}$ & Model II & Model I2 \\
\hline $\begin{array}{l}\text { Fixed effects } \\
\text { Issue-specific cabinet conflict }\end{array}$ & 0.144 & -0.167 \\
& $(0.154)$ & $(0.210)$ \\
Preference tangentiality & $0.179 *$ & $0.707 * * *$ \\
& $(0.107)$ & $(0.195)$ \\
Joint salience & $0.573^{* * * *}$ & $0.519 * * *$ \\
& $(0.034)$ & $(0.059)$ \\
\hline & & (continued)
\end{tabular}


Table A7. (continued)

Dependent variable: Issue attention in coalition agreements

Model II

Model 12

\begin{tabular}{lcc}
\hline Effective number of parliamentary parties & 0.140 & 0.202 \\
& $(0.231)$ & $(0.229)$ \\
Number of cabinet parties & 0.104 & 0.074 \\
& $(0.279)$ & $(0.275)$ \\
Minority status & 0.707 & 0.451 \\
& $(0.698)$ & $(0.689)$ \\
Minimal winning status & 0.372 & 0.339 \\
& $(0.576)$ & $(0.567)$ \\
Issue-specific cabinet conflict $\times$ Preference & $-0.068^{*}$ & $-0.144^{*}$ \\
tangentiality & $(0.040)$ & $(0.082)$ \\
Issue-specific cabinet conflict $\times$ Joint & & $0.079 * * *$ \\
salience & & $(0.026)$ \\
Preference tangentiality $\times$ Joint salience & & $-0.03 I^{* *}$ \\
& & $(0.013)$ \\
Conflict $\times$ Preference tangentiality $\times$ Joint & & -0.001 \\
salience & & $(0.006)$ \\
Constant & & \\
Random effects & & 1.416 \\
Country-level variance & & $(0.619)$ \\
Cabinet-level variance & & 13.390 \\
$N$ Log likelihood & $(0.605)$ & $(0.785)$ \\
Akaike information criterion & 14.106 & 605 \\
\hline
\end{tabular}

$*_{p}<.10 . *_{p}<.05 . *_{*}^{*} p<.01$.

\section{Appendix B}

\section{Creating a Data Set on the Content of Coalition Agreements}

Case selection and collection of coalition agreements. Following Müller and Strøm (2008), we define coalition agreements as "the most binding, written statements to which the parties of a coalition commit themselves, that is, the most authoritative document that constrains party behaviour" 
(p. 170, emphasis in original). We only include postelectoral and interelectoral coalition agreements in our data set as they are negotiated after the bargaining strength, most important, the share of parliamentary seats parties won in elections, is given. Preelectoral coalition agreements are excluded as they are drafted before an election without knowledge of the future parliamentary strength. We have compiled a new data set that encompasses 229 postelectoral and interelectoral coalition agreements negotiated by governing parties in 24 West and East European countries from 1945 until 2015. ${ }^{11}$ These countries include Austria, Belgium, Bulgaria, the Czech Republic, Denmark, Estonia, Finland, Germany, Greece, Hungary, Iceland, Ireland, Latvia, Lithuania, Luxembourg, the Netherlands, Norway, Poland, Portugal, Romania, Slovakia, Slovenia, Sweden, and the United Kingdom. ${ }^{12}$ The selection of countries follows the established standard in coalition research and only includes European democracies that were governed by coalition cabinets and that have publicly released a coalition agreement at least once in the time period under investigation (see also Andersson et al., 2014).

To identify coalition agreements in all the countries in our sample, we followed the criteria developed by Bergman (2000, p. 214): First, political parties have to regard a document as the most central and binding text to qualify as a coalition agreement. As the document is of high importance for lawmaking, parties should, second, have invested time and effort in the bargaining process, and, third, the document needs to be publicly available. In some countries (e.g., Germany, the Netherlands), identifying coalition agreements was straightforward because coalition parties officially publish documents that are literally called "coalition agreements" in their respective languages, and the media reports extensively about these contracts. However, in other countries (e.g., Austria, Sweden), cabinet parties do not present an official "coalition agreement," but they negotiate other documents that fulfill the same function (e.g., government declarations in Sweden). In some Central and Eastern European (CEE) countries (e.g., Latvia and Slovakia), there is not a single document that falls under our definition of coalition agreements, but parties negotiate multiple documents. Typically, the documents termed "coalition agreements" are restricted to procedural rules, and they need to be complemented with other documents where cabinets have laid out their negotiated policy agendas. In such cases, we coded not only the procedural coalition agreements but also the government programs. Table B1 provides an overview over the coalition agreements included in our sample. 
Table B I. Sample of Coalition Agreements From 1945 to 2015.

\begin{tabular}{lc}
\hline Country & Number of coalition agreements \\
\hline Austria & 15 \\
Belgium & 20 \\
Bulgaria & 1 \\
Czech Republic & 6 \\
Denmark & 8 \\
Estonia & 11 \\
Finland & 33 \\
Germany & 14 \\
Greece & 2 \\
Hungary & 5 \\
Iceland & 22 \\
Ireland & 9 \\
Latvia & 17 \\
Lithuania & 5 \\
Luxembourg & 4 \\
The Netherlands & 16 \\
Norway & 3 \\
Poland & 7 \\
Portugal & 224 \\
Romania & 4 \\
Slovakia & 3 \\
Slovenia & 4 \\
Sweden & 7 \\
United Kingdom & 7 \\
\hline Total & 1 \\
\hline
\end{tabular}

\section{Acknowledgments}

We thank Svenja Krauss, Christoph Uhl, Paul Bochtler, Cornelius Erfort, Lukas Hetzer, Lisa Reiber, Marius Sältzer, and Stefan Papantonatos for valuable research assistance. We are furthermore indebted to the country experts for their assistance in identifying and/or sharing coalition agreements, respectively, and for the native language coders for coding the coalition agreements. We are grateful to the German Research Foundation for funding this study. We finally thank Royce A. Carroll, David Fortunato, and Yannis Vassiliadis for valuable comments and suggestions.

\section{Declaration of Conflicting Interests}

The authors declared no potential conflicts of interest with respect to the research, authorship, and/or publication of this article. 


\section{Funding}

The authors disclosed receipt of the following financial support for the research, authorship, and/or publication of this article: This study was funded by the German Research Foundation (DFG; Grant KL 2692/1-1).

\section{ORCID iD}

Heike Klüver (iD) https://orcid.org/0000-0003-4838-0754

\section{Notes}

1. Other control mechanisms that have been discussed in the literature include "watchdog" junior ministers who can "keep tabs" on the senior minister (Lipsmeyer \& Pierce, 2011; Thies, 2001). Among control mechanisms functioning at the parliamentary arena (see, for example, Strøm, Müller, \& Smith, 2010), some scholars have analyzed the appointment of committee chairs (see, for example, Carroll \& Cox, 2012; Kim \& Loewenberg, 2005). Some previous research has also shown that parliamentary committees can enable "ministerial correction" (Martin \& Vanberg, 2011).

2. An important avenue for future research in this regard is how ideological conflict and transaction as well as audience costs influence coalition negotiations more generally. For instance, are transaction and audience costs particularly high for parties with diverse ideological profiles, and could this explain why some coalition negotiations fail?

3. For a thorough description and graphical presentation of the concept of tangentiality, see Falcó-Gimeno (2014, p. 344).

4. The process for creating this data set is described in more detail in Appendix B. As matching the coalition agreement data set with data from the Manifestos Project (MP; Volkens et al., 2017) is necessary for the analysis conducted in this article, the number of coalition agreements reduced from 229 agreements included in our original data set to 224 agreements as the MP has not (yet) coded the respective election manifestos for six of our cabinets.

5. We have estimated an additional model specification, where we rely on an issue attention measure that is calculated only on the basis of policy-relevant text in the coalition agreements. More precisely, to calculate this alternative issue attention measure, we have removed all quasi-sentences devoted to procedural rules as well as all quasi-sentences that fall into the "others" category (related neither to policy nor to procedural rules) before calculating the percentage of quasi-sentences that are devoted to different policy categories. The results are presented in Table A4 in Appendix A, and are substantially the same as the results obtained using our specification.

6. This scaling approach is based on salience theory, which assumes that policy positions are revealed by the number of statements devoted to an issue (Budge, Klingemann, Volkens, Bara, \& Tanenbaum, 2001, pp. 6-7). 
7. We have additionally estimated a robustness check, in which we also control for cabinet type (see Table A5 in Appendix A). The results are substantially the same.

8. An exception may be the case of "agricultural," or farmers' parties in Scandinavian countries.

9. To test the robustness of the findings, we have also estimated a multilevel tobit regression, as the dependent variable can only take on values between 0 and 100 (see Table A6 in Appendix A). The results are essentially the same as the findings we obtain using the linear multilevel model, and we, therefore, rely on the more parsimonious model specification that allows for more intuitive interpretation.

10. The three-way interaction term is also negative in all robustness checks presented in Appendix A and even statistically significant when including issue fixed effects.

11. As matching the coalition agreement data set with data from the MP (Volkens et al., 2017) is necessary for the analysis conducted in this article, the number of coalition agreements reduced from 229 agreements included in our original data set to 224 agreements as the MP has not (yet) coded the respective election manifestos for five of our cabinets.

12. We excluded Italy and France from our sample because the electoral system works against writing postelectoral coalition agreements. Cyprus was excluded due to its presidential system.

\section{References}

Andersson, S., Bergman, T., \& Ersson, S. (2014). The European representative democracy data archive, Release 3 (Main sponsor: Riksbankens Jubileumsfond [In2007-0149:1-E]). Available from www.erdda.se

Andeweg, R. B. (2000). Ministers as double agents? The delegation process between cabinet and ministers. European Journal of Political Research, 37, 377-395.

Bäck, H., Debus, M., \& Dumont, P. (2011). Who gets what in coalition governments? Predictors of portfolio allocation in parliamentary democracies. European Journal of Political Research, 50, 441-478.

Bäck, H., Debus, M., \& Müller, W. C. (2016). Intra-party diversity and ministerial selection in coalition governments. Public Choice, 166, 355-378.

Bäck, H., Müller, W. C., \& Nyblade, B. (2017). Multiparty government and economic policy-making. Coalition agreements, prime ministerial power and spending in Western European cabinets. Public Choice, 170, 33-62.

Bergman, T. (2000). When minority cabinets are the rule and majority coalitions the exception. In W. C. Müller \& K. Strøm (Eds.), Coalition governments in Western Europe (pp. 192-230). Oxford, UK: Oxford University Press.

Bowler, S., Bräuninger, T., Debus, M., \& Indridason, I. H. (2016). Let's just agree to disagree: Dispute resolution mechanisms in coalition agreements. The Journal of Politics, 78, 1264-1278.

Brambor, T., Clark, W. R., \& Golder, M. (2006). Understanding interaction models: Improving empirical analyses. Political Analysis, 14, 63-82. 
Budge, I., (1999). Estimating party policy peferences: From ad hoc measures to theoretically validated standards. Essex Papers in Politics and Government, 139.

Budge, I., Klingemann, H.-D., Volkens, A., Bara, J., \& Tanenbaum, E. (2001). Mapping policy preferences: Estimates for parties, electors, and governments 1945-1998. Oxford, UK: Oxford University Press.

Budge, I., \& Farlie, D. J. (1983). Explaining and predicting elections: Issue effects and party strategies in twenty-three democracies. London: George Allen and Unwin.

Carroll, R., \& Cox, G. W. (2012). Shadowing ministers: Monitoring partners in coalition governments. Comparative Political Studies, 45, 220-236.

Döring, H. (2013). The collective action of data collection: A data infrastructure on parties, elections and cabinets. European Union Politics, 14, 161-178.

Döring, H., \& Manow, P. (2016). Parliaments and governments database (ParlGov): Information on parties, elections and cabinets in modern democracies (Development version). Retrieved from http://www.parlgov.org/\#data

Eichorst, J. (2014). Explaining variation in coalition agreements: The electoral and policy motivations for drafting agreements. European Journal of Political Research, 53, 98-115.

Falcó-Gimeno, A. (2014). The use of control mechanisms in coalition governments: The role of preference tangentiality and repeated interactions. Party Politics, 20, 341-356.

Green-Pedersen, C. (2007). The growing importance of issue competition. The Changing Nature of Party Competition in Western Europe, Political Studies, 55(4), 608-628.

Huber, J. D., \& Shipan, C. R. (2002). Deliberate Discretion? The Institutional Foundations of Bureaucratic Autonomy. Cambridge: Cambridge University Press.

Indridason, I. H., \& Kam, C. (2008). Cabinet reshuffles and ministerial drift. British Journal of Political Science, 38, 621-656.

Indridason, I. H., \& Kristinsson, G. H. (2013). Making words count: Coalition agreements and cabinet management. European Journal of Political Research, 52, 822-846.

Kam, C., Bianco, W. T., Sened, I., \& Smyth, R. (2010). Ministerial selection and intraparty organization in the contemporary British parliament. American Political Science Review, 104, 289-306.

Kim, D.-H., \& Loewenberg, G. (2005). The role of parliamentary committees in coalition governments: Keeping tabs on coalition partners in the German bundestag. Comparative Political Studies, 38, 1104-1129.

King, G., Tomz, M., \& Wittenberg, J. (2000). Making the most of statistical analyses: Improving interpretation and presentation. American Journal of Political Science, 44, 341-355.

Klingemann, H.-D., Volkens, A., Bara, J., Budge, I., \& McDonald, M. (Eds.). (2006). Mapping policy preferences: Estimates for parties, electors and governments in Eastern Europe, European Union and OECD 1990-2003. Oxford, UK: Oxford University Press. 
Klüver, H., \& Spoon, J.-J. (2016). Who responds? Voters, parties, and issue attention. British Journal of Political Science, 46, 633-654.

Laver, M., \& Shepsle, K. A. (1996). Making and breaking governments. Cambridge: Cambridge University Press.

Linhart, E., \& Pappi, F. U. (2009). Koalitionsbildungen zwischen Ämter- und Politikmotivation. Konstruktion einer interdependenten Nutzenfunktion [Coalition formation between offices and policies: Contruction of an interdependent utility function]. Politische Vierteljahresschrift, 50(1), 23-49.

Lipsmeyer, C., \& Pierce, H. N. (2011). The eyes that bind: Junior ministers as oversight mechanisms in coalition governments. Journal of Politics, 73, 1152-1164.

Martin, L. W., \& Vanberg, G. (2011). Parliaments and coalitions. The role of legislative institutions in multiparty governance. Oxford, UK: Oxford University Press.

Moury, C. (2011). Coalition agreement and party mandate: How coalition agreements constrain the ministers. Party Politics, 17, 385-404.

Moury, C., \& Timmermans, A. (2013). Inter-party conflict management in coalition governments: Analyzing the role of coalition agreements in Belgium, Germany, Italy and the Netherlands. Politics and Governance, 1, 117-131.

Müller, W. C., \& Meyer, T. (2010). Meeting the challenges of representation and accountability in multiparty governments. West European Politics, 33, 1065 1092.

Müller, W. C., \& Strøm, K. (2008). Coalition agreements and cabinet governance. In K. Strøm, W. C. Müller, \& T. Bergman (Eds.), Cabinet governance: Bargaining and the cycle of democratic politics (pp. 159-199). Oxford, UK: Oxford University Press.

Petrocik, J. (1996). Issue ownership in presidential elections, with a 1980 case study. American Journal of Political Science, 40(3), 825-850.

Schermann, K., \& Ennser-Jedenastik, L. (2014). Explaining coalition-bargaining outcomes: Evidence from Austria, 2002-2008. Party Politics, 20, 791-801.

Shikano, S., \& Linhart, E. (2010). Coalition formation as a result of policy and office motivations in the German federal states: An empirical estimation of the weighting parameters of both motivations. Party Politics, 16, 111-130.

Spoon, J.-J., \& Klüver, H. (2014). Do parties respond? How electoral context influences party responsiveness. Electoral Studies, 35, 48-60.

Spoon, J.-J., \& Klüver, H. (2015). Voter polarization and party responsiveness: Why parties emphasize divided issues, but remain silent on unified issues. European Journal of Political Research, 54, 343-362.

Steenbergen, M. R., \& Jones, B. S. (2002). Modeling multilevel data structures. American Journal of Political Science, 46, 218-237.

Strøm, K. (2003). Parliamentary democracy and delegation. In K. Strøm, W. C. Müller, \& T. Bergman (Eds.), Delegation and accountability in parliamentary democracies (pp. 55-109). Oxford, UK: Oxford University Press.

Strøm, K., \& Müller, W. C. (1999). The keys to togetherness: Coalition agreements in parliamentary democracies. The Journal of Legislative Studies, 5, 255-282.

Strøm, K., Müller, W. C., \& Bergman, T. (Eds.). (2003). Delegation and accountability in parliamentary democracies. Oxford, UK: Oxford University Press. 
Strøm, K., Müller, W. C., \& Bergman, T. (Eds.). (2008). Cabinets and coalition bargaining: The democratic life cycle in Western Europe. Oxford, UK: Oxford University Press.

Strøm, K., Müller, W. C., \& Smith, D. M. (2010). Parliamentary control of coalition governments. Annual Review of Political Science, 13, 517-535.

Thies, M. F. (2001). Keeping tabs on partners: The logic of delegation in coalition governments. American Journal of Political Science, 45, 580-598.

Timmermans, A., \& Gerard, B. (2011). The policy agenda in multiparty government: Coalition agreements and legislative activity in the Netherlands. Paper presented at the ECPR Joint Sessions, St. Gallen, 13-17 April 2011.

Timmermans, A. (2006). Standing apart and sitting together: Enforcing coalition agreements in multiparty systems. European Journal of Political Research, 45, 263-283.

Tsebelis, G. (2002). Veto players: How political institutions work. Princeton, NJ: Princeton University Press.

van de Wardt, M., de Vries, C. E., \& Hobolt, S. B. (2014). Exploiting the cracks: Wedge issues in multiparty competition. Journal of Politics, 76(4), 986-999.

Volkens, A., Lehmann, P., Matthieß, T., Merz, N., Regel, S., \& Weßels, B. (2017). The manifesto data collection. Manifesto project (MRG/CMP/MARPOR, Version 2017b). Berlin, Germany: Wissenschaftszentrum Berlin für Sozialforschung. doi:10.25522/manifesto.mpds.2017b

\section{Author Biographies}

Heike Klüver is professor of Comparative Political Behavior at Humboldt-Universität zu Berlin. Her research interests include political parties, coalition governments, interest groups and quantitative text analysis. She has published her work among others at Oxford University Press, in the American Journal of Political Science, the Journal of Politics, the British Journal of Political Science, and the European Journal of Political Research.

Hanna Bäck is professor of Political Science at Lund University. Her research interests include political parties, coalition governments, legislative behavior and political psychology. She has published her work in journals such as the British Journal of Political Science, the European Journal of Political Research, and Political Science Research and Methods. 